\title{
Effect of building Form, Orientation, and Thermal Insulation on Energy Consumption In Air-Conditioned Desert Buildings.
}

\author{
Khaled El-Deed1* Ahmed Sherif 2, Abbas El-Zafarany 3. \\ ${ }^{1}$ Department of Architecture, Faculty of Fine Arts, Alexandria University, Egypt. \\ 2 School of Sciences and Engineering, The American University in Cairo. \\ ${ }^{3}$ Faculty of Urban and Regional Planning, Cairo University, Egypt.
}

\begin{abstract}
Passive solar architecture strategies such as adjusting building form and orientation, and using thermal insulation to improve users' comfort are commonly used. Nowadays, an increasing number of buildings are air-conditioned, and some passive techniques may not yield the anticipated energy reduction in these buildings. In addition, some strategies might seem contradictory such as decreasing the exposed surface area of building and that of setting large ones but thermally insulated.
\end{abstract}

This paper questions the effect of building form and orientation on the energy consumption of air-conditioned low-rise residential buildings in comparison to that of using thermal insulation in external walls for different desert environments. A base case of a squared two-storey residential building was simulated using the Energy-Plus software in three cities: Jeddah, Cairo and Alexandria. It was compared with other building forms: rectangles of different proportions, $L, U$, $\mathrm{H}$-shaped forms and a squared courtyard building.

Results showed that common desert building forms do not always yield the expected reduction of energy consumption. The un-insulated courtyard building consumed $15 \%$ more energy in comparison with the square shaped building in the extreme hot climate of Jeddah, but when insulated, its performance improved to achieve savings of $17 \%$, which was more than the savings achieved by the insulated solid square. This trend was evident to a less extent in Alexandria; the courtyard reached $5 \%$ increase of energy consumption, while the insulated one reached $19 \%$ savings, to be one of the highest efficiency forms.

The effect of orientation varied according to the proportions of the forms, and thus, to the increase or decrease of the portion of surface area subjected to direct solar radiation. In general, thermal insulation proved to be of a higher effect than building form and orientation in almost all cases.

Keywords: Building form, Thermal insulation, energy-efficient, simulation, air-conditioned desert buildings.

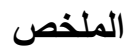

من المتعارف عليه معماريا استخدام استر اتيجيات التصميم المعمارى السلبى كتشكيل كتلة المبنى و التوجيه و دراسة العزل

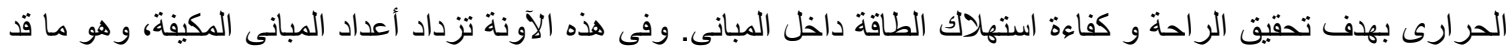

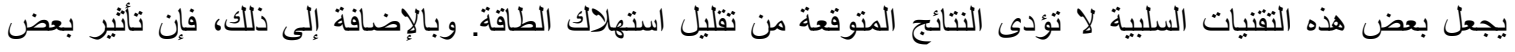




$$
\begin{aligned}
& \text { الاستر اتيجيات قد تبدو محل تباين مما يثير التساؤل، متل معرفة أبهما أكثر تأثير ا: الإقلال من مسطح غلاف المبنى المعرض إنى }
\end{aligned}
$$

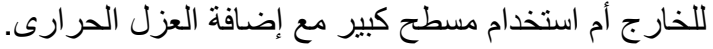

$$
\begin{aligned}
& \text { هذه الورقة البحثية تقوم بدر اسة تأثير تثكيل كتلة المبنى والتوجيه على استهلاك الطاقة فى المبانى السكنية المكيفة منخفضة } \\
& \text { الارتفاع، ومقارنته بتأثير استخدام العزل الحر ارى للحو ائط الخارجية فى بيئات صحر اوية مختلفة. } \\
& \text { باستخدام برمجيات الحاسب الآلى المعتمدة للنمذجة والمحاكاه، تمت محاكاة استهلاك الطاقة لحالة أساسية لمبنى سكنى مكيف }
\end{aligned}
$$

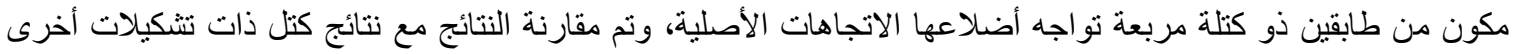

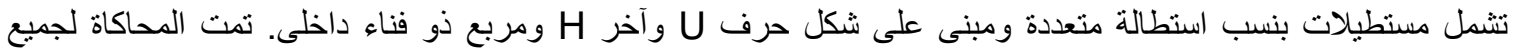

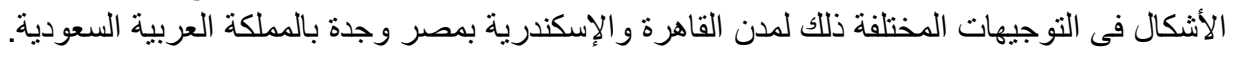

$$
\begin{aligned}
& \text { أظهرت النتائج أن الأشكال المتعارف عليها لعمارة الصحر اء قد لا تؤدى دائما إلى النتائج المنوقعة منها من تقليل لاستهلاك الكئك }
\end{aligned}
$$

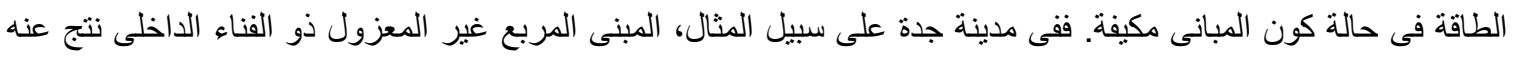

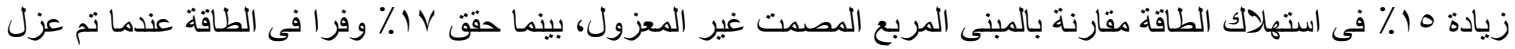

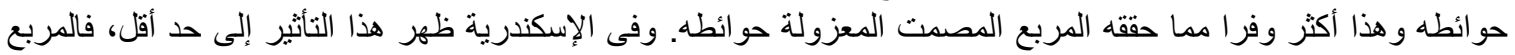

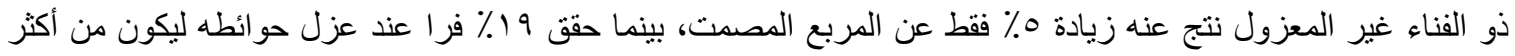

$$
\begin{aligned}
& \text { الأشكال كفاءة فى استهلاك الطاقة. } \\
& \text { وبهدف المقارنة بمدينة ذات مناخ مختلف عن المدن الصحر اوية، تمت الدراسة أيضا لمدينة برلين بألمانيا. }
\end{aligned}
$$

\section{Introduction}

Passive techniques have been commonly used to mitigate the effect of the local climate and to improve comfort inside buildings located in desert environments. Design of the building form, selecting the appropriate orientation and using thermal insulation were issues of importance in passive architecture.

Nowadays, an increasing number of desert buildings are air-conditioned. It seems intuitive to use passive techniques to minimize energy consumption. However, the performance of these techniques in case of air-conditioned buildings is questionable and requires careful examination. For example, the self-shaded naturally ventilated courtyard buildings are typically recommended for desert environments, while the increase in the exposed surface area of a building is typically not recommended in desert climates as the building will be more subjected to outdoor conditions and more liable to heat transfer between the indoor and the outdoor. In this case, a careful investigation is needed as natural ventilation is not a key issue in air-conditioned courtyard buildings.

As such, a number of research questions are raised: 
What is the energy-efficiency ranking of building forms located in desert environments? Which is of more effect on the energy performance: building form, orientation or thermal insulation? How much is that effect? Does the same effect apply to all desert cities? Can thermal insulation eliminate the negative effect of the increased surface area? Does thermal insulation have the same effect on all forms in a certain city? Can it change the rank of building forms if ordered according to energy-efficiency?

All these questions reflect the need for evaluating the validity of the commonly known assumptions and for quantifying the effects of building form, orientation and thermal insulation as passive techniques when applied in air-conditioned buildings located in desert climates.

Literature showed that the effect of building form as a passive strategy was discussed in numerous research work:

The effect of building form on energy consumption was addressed by Depecker et al. [1] in which the energy consumed for heating was related to the building form through a shape coefficient that related external surface area to the inner volume. It showed to be more applicable to cold climates with medium or short periods of sunshine. Oral et al. [2] addressed the limit values of heat transfer coefficient with respect to external surface area-to-volume ratio of building forms aiming at minimizing heat loss in cold climates.

Okeil A. [3] proposed a multi-storey residential building form derived by cutting solar profiles in a conventional block that aimed to maximize the potential of passive utilization of solar energy by maximizing solar energy falling on facades while minimizing that falling on roofs and on the ground surrounding buildings in an urban area in winter. The building was studied for latitude 480, where solar exposure was the main issue, which might not apply to hot desert climates. Hachem et al. [4, 5] studied the effect of a number of geometric forms and clustering alternatives on the solar potential of housing units. Kämpf and Robinson [6], and Kämpf et al. [7] performed an optimization process for the building and urban geometric forms to maximize the utilization of solar irradiation incident on the building envelope. Ratti et al. [8] studied the effect of building form on the environmental performance on the urban scale addressing shadow density and daylight distribution in street.

Courtyard building forms were examined in numerous studies. The shading performance of different polygonal courtyard forms was examined by Muhaisen and Gadi, [9]. The effect of courtyard proportions on solar heat gain and consequently on cooling and heating energy requirements was studied in the temperate climate of Rome using solid forms with no external windows [10]. It was found that the geometrical shape of the courtyard had a very small effect on shading in winter in comparison with summer; and courtyards with deep proportions were recommended over shallow ones. However, in both studies the tested buildings were solid with no windows, and thus both the effect 
of transmitted solar radiation and the energy needed for artificial lighting were not considered.

The effect of a naturally ventilated courtyard on thermal performance was studied in hot arid, tropical and warm humid tropical climates $[11,12,13]$. In these publications, the effect of courtyard presence, ventilation in daytime and/or night-time, presence of a water pool as well as courtyard shading was addressed. Results indicated that a courtyard building with controlled natural ventilation, of specified opening time, type of ventilation and position of openings improved thermal performance. However in the hot arid climate, the thermal performance resulting from continuous day and night natural ventilation was worse than keeping the building closed without natural ventilation [11].

Safarzadeh and Bahadori studied the passive effect of courtyard use on energy consumed for heating and cooling, including the effect of shading, planting and water pool [14]. It was found that these passive features alone could not maintain comfort during the hot summer times in the city of Tehran, Iran and that similar effects could be obtained through thermal insulation of walls and roof, double glazing, use of Persian blinds and infiltration-reduction. However, the energy needed for artificial lighting that compensates for the effect of shading was not accounted for.

The effect of building orientation on thermal performance was addressed by Al-Tamimi et al. [15] for non-air-conditioned buildings in hot-humid climate while Morissey et al. [16] studied the implications of orientation on thermal energy efficiency in Melbourne, Australia.

Literature showed that the quantitative analysis for the impact of building forms, orientation, and passive treatments such as thermal insulation in case of two-storey residential air-conditioned buildings located in desert environments are not sufficiently addressed and needs more investigation.

\section{Objectives}

This research aims to quantify, evaluate and compare the effect of building form, orientation and wall thermal insulation - as passive techniques - on energy consumption of air-conditioned two-storey residential buildings located in different desert climates.

\section{Methodology}

To evaluate the effect of building form and orientation, eight building forms were tested. Rectangular forms of proportions 1:1 (square), 1:1.5, 1:2 and 1:4, in addition to a square courtyard building, and $\mathrm{U}, \mathrm{H}$ and L-shaped buildings were modelled and simulated for energy performance. 
The solid square building was used as a base case. Analysis was performed by comparing the energy consumption of the tested building forms to that of the base case. Percentage of change in consumption was calculated and compared accordingly.

The building forms were tested in eight orientations. As the square building was symmetric about its axes, only the $\mathrm{N}$ and NE orientations were displayed representing the eight orientations. The same was done for all forms.

To evaluate the effect of wall thermal insulation, a layer of $5 \mathrm{~cm}$ insulation was added to the walls. Then, these wall-insulated buildings were simulated for energy performance and compared to the base case. Table 1 shows the tested building forms.

Table (1) Simulated cases of building forms

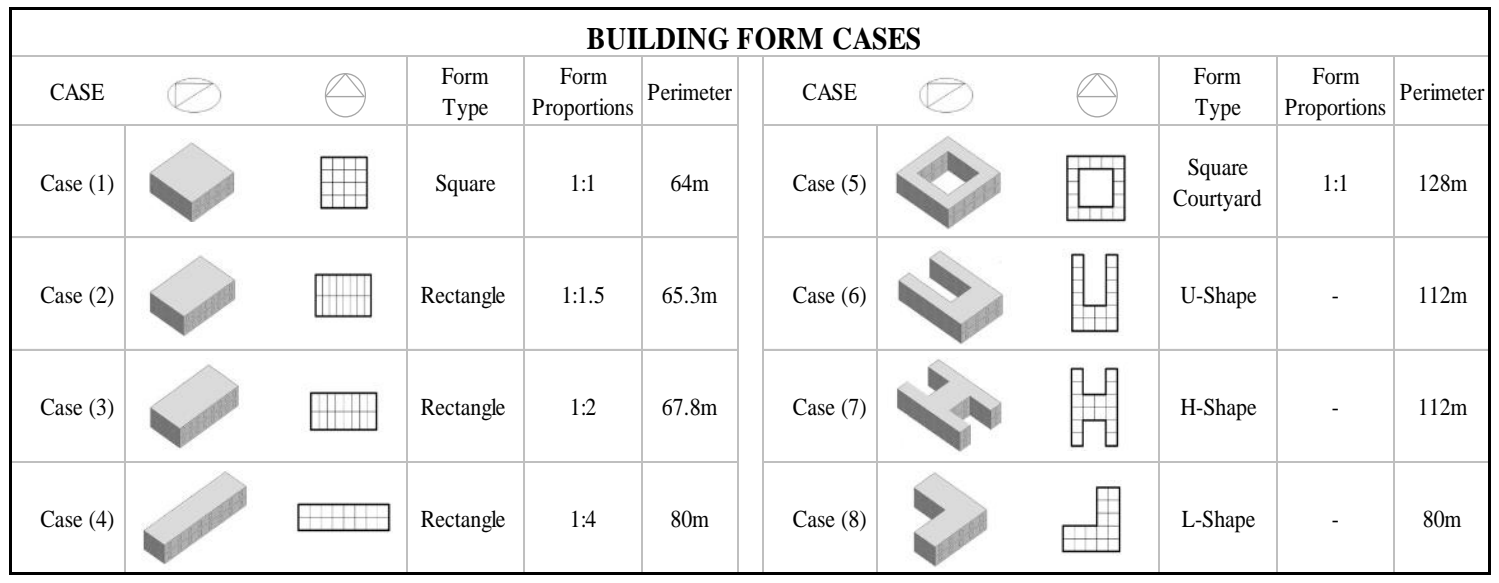

The alternatives were modelled using the Design Builder software and simulated for energy performance using the Energy Plus. Loads for both the HVAC and artificial lighting systems were considered.

Energy simulation was performed for three desert cities: Jeddah (Saudi Arabia), Cairo (Egypt) and Alexandria (Egypt). They were classified as hot-arid desert according to Köppen-Geiger climate classification [12]. However, there are differences between the three cities in regards to temperature ranges despite being of the same classification. For comparison purpose, simulations were also performed for a city of a temperate climate; Berlin, that was classified as a warm temperate city with fully humid warm summer [12].

Temperature is generally higher in Jeddah than all other cities all year round, even in winter time where it reaches about $30^{\circ} \mathrm{C}$. Cairo maximum temperature is generally higher than that of Alexandria, especially in summer, Figure 1. 
Figure (1) Monthly mean daily dry-bulb temperatures in tested cities.

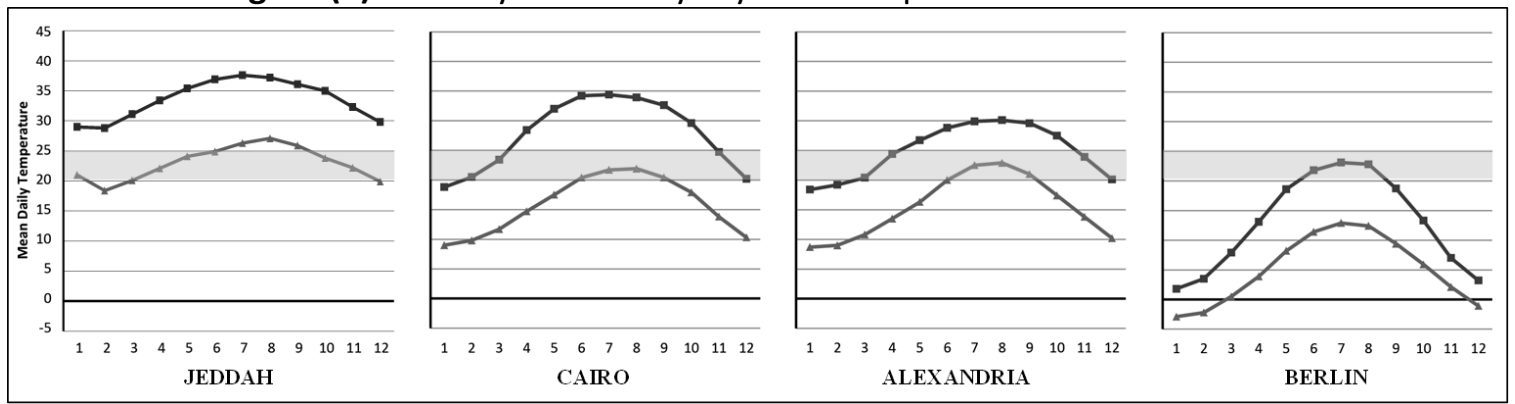

By comparison, temperature ranges in Berlin are generally colder than the other cities. The maximum temperature in Berlin is nearly similar to the minimum values in Cairo and Alexandria, especially in summer.

\section{Parameters}

A two-storey residential building of $256 \mathrm{~m}^{2} /$ floor area was modelled. It represents a typical single family house in Saudi Arabia. It could also represent a single high-end family residence or a several family dwelling in Egypt. The building size was selected to fit common new residential land lots in Egypt and Saudi Arabia. They usually range from 500 to $600 \mathrm{~m}^{2}$, while building regulations usually specify a maximum allowable built area of $50 \%$ of land area, resulting in a $250 \mathrm{~m}^{2}$ floor area.

Table (2) Simulation parameters for tested building forms.

\begin{tabular}{|c|c|c|c|c|c|c|c|c|c|}
\hline \multicolumn{10}{|c|}{ SIMULATION PARAMETERS } \\
\hline \multicolumn{2}{|l|}{ BUILDING } & \multirow[b]{2}{*}{ No. of people } & \multirow[b]{2}{*}{7} & \multirow{2}{*}{$\begin{array}{l}\text { HVAC } \\
\text { Cooling }\end{array}$} & \multirow{2}{*}{$\begin{array}{l}\text { Setpoint } \\
23\end{array}$} & \multirow{2}{*}{$\begin{array}{l}\text { setback } \\
28\end{array}$} & \multirow{2}{*}{$\begin{array}{l}\text { LIGHTING } \\
\text { Type }\end{array}$} & \multirow[b]{2}{*}{ Fluorescent } & \multirow[b]{2}{*}{ Suspended } \\
\hline Area/floor & $256 \mathrm{~m} 2$ & & & & & & & & \\
\hline Total Area & $512 \mathrm{~m} 2$ & Ground floor & Living & Heating & 22 & 12 & \multicolumn{3}{|c|}{ Daylighting control } \\
\hline $\begin{array}{l}\text { No. of } \\
\text { zones/floor }\end{array}$ & 16 & First floor & Bedroom & Type & Split & & $\begin{array}{l}\text { illuminance: } \\
200 \text { lux }\end{array}$ & $\begin{array}{l}\text { Dimming: } \\
\text { On/off }\end{array}$ & $\begin{array}{l}\text { Sensor Height: } \\
0.8 \mathrm{~m}\end{array}$ \\
\hline \multicolumn{10}{|c|}{ CONSTRUCTION } \\
\hline \multicolumn{2}{|c|}{ External walls } & \multicolumn{8}{|c|}{$20 \mathrm{~cm}$ concrete block $+2 \mathrm{~cm}$ cement plaster each side } \\
\hline \multicolumn{2}{|c|}{$\begin{array}{l}\text { External walls } \\
\text { (Insualted) }\end{array}$} & \multicolumn{8}{|c|}{2 layers of $10 \mathrm{~cm}$ concrete block $+5 \mathrm{~cm}$ polystyrene foam in the middle $+2 \mathrm{~cm}$ cement plaster each side } \\
\hline \multicolumn{2}{|l|}{ Internal walls } & \multicolumn{8}{|c|}{$10 \mathrm{~cm}$ concrete block $+2 \mathrm{~cm}$ cement plaster each side } \\
\hline \multicolumn{2}{|l|}{ Roof } & \multicolumn{8}{|c|}{ Insulated with $10 \mathrm{~cm}$ polystyrene foam } \\
\hline \multicolumn{2}{|l|}{ Internal slab } & \multicolumn{8}{|c|}{$20 \mathrm{~cm}$ concrete $+10 \mathrm{~cm}$ flooring $+2 \mathrm{~cm}$ plaster } \\
\hline \multicolumn{2}{|l|}{ Windows } & Area & \multicolumn{2}{|c|}{ "Square" WWR } & xed for all & 1 forms & Type & \multicolumn{2}{|c|}{ Double-glazed clear } \\
\hline
\end{tabular}

In the modelling process, buildings were hypothetically divided into 16 zones/floor, each of $16 \mathrm{~m}^{2}$ in area. The floor height was assumed to be $3 \mathrm{~m}$. Total window area was fixed for all forms. It was calculated to provide $20 \%$ window- to-wall ratio (WWR) of the 'square' case. Simulation parameters are shown in Table 2. 


\section{Results and Discussion}

Simulation results reflected the impact of climate conditions on energy consumption across the tested cities. Results came as follows:

\section{Base Case results:}

Base case results, Figure 2, showed that energy consumption was highest in Jeddah. Energy use intensity (EUI) reached $133 \mathrm{Kwhr} / \mathrm{m}^{2}$ per year, highly dominated by cooling loads of $112 \mathrm{Kwhr} / \mathrm{m}^{2}$, no heating loads and $21 \mathrm{Kwhr} / \mathrm{m}^{2}$ lighting loads. Cairo and Berlin were of a nearly similar annual EUI of 79 and $80 \mathrm{Kwhr} / \mathrm{m}^{2}$ respectively, but with a difference in loads distribution; Cairo was cooling dominated with small heating loads of only $3 \mathrm{Kwhr} / \mathrm{m}^{2}$, while on the other hand, the heating loads were dominant in Berlin where cooling loads did not exceed $7 \mathrm{Kwhr} / \mathrm{m}^{2}$ only. The EUI of the base case in Alexandria was the minimum, and reached $66 \mathrm{Kwhr} / \mathrm{m}^{2}$ dominated by cooling loads.

Lighting loads of the base case were of small differences across cities, where the consumption was 21, 22, 23 and $24 \mathrm{Kwhr} / \mathrm{m}^{2}$ in Jeddah, Cairo, Alexandria and Berlin respectively, However, it reflected the increase in need for artificial lighting in cities of higher latitudes.

Figure (2) Energy use intensity of base case across tested cities.

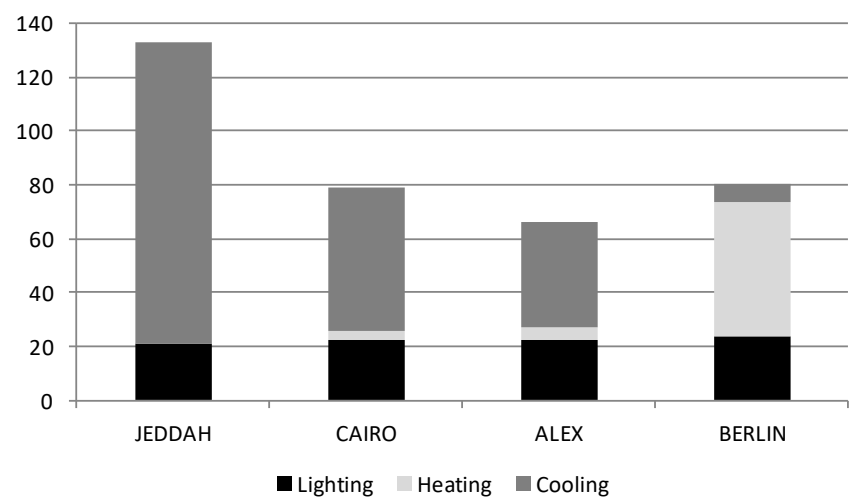

\section{Effect of Form and Orientation:}

Results of tested building forms differed according to orientation. Forms consumed minimum energy when their longer sides were facing north and south, while consumed highest energy when the longer sides faced east and west. Values of energy consumption in secondary orientations (NE, SE, SW and NW) were between those of the former orientations. Forms having sides of length proportions 1:1 (solid square, and square with courtyard) consumed less energy when faced the principal orientations, while a small increase occurred when faced secondary orientations. The amount of change in energy consumption due to orientation differed according to the form and city. 
Forms of higher difference in proportions - such as Rectangle 1:4 - were more sensitive to change in orientation, as the amount of solar radiation received by the building envelope decreased significantly when the long façade faces the north. In forms where change in orientation did not result in a significant change in the surface area of façade subjected to solar radiation - such as square, courtyard and L-shape - the change in consumption due to orientation was not significant. In Jeddah, Cairo and Alexandria, the change in orientation had a significant effect, while the effect was very small in the temperate climate of Berlin.

In Jeddah, Figure 3, results showed that all forms were higher in consumption than the base case, expect for rectangular cases that achieved savings only when oriented to north. In this orientation, the rectangle 1:4 was the most efficient tested form as it achieved savings of about $5 \%$, followed by rectangle 1:2 (4.3\%) and rectangle 1:1.5 (2.6\%). They were followed by the north-oriented square base case, then by the L-shape that lead to an increase of $2 \%$ to $3.6 \%$ according to orientation. The $\mathrm{H}$-shape increased consumption by a range $2.6 \%$ to $10.8 \%$, while the $U$-shape was higher by a range of $3.8 \%$ to $12.3 \%$.

The form of highest energy consumption was the courtyard building that lead to an increase of $15 \%$ and $16.6 \%$ when oriented to principal and secondary orientations respectively. This can be explained as the courtyard building was the form of the largest surface area, and thus, the most exposed outdoor conditions.

Figure (3) Energy use intensity of forms with walls un-insulated in Jeddah and percentage of change in energy consumption compared to the base case.
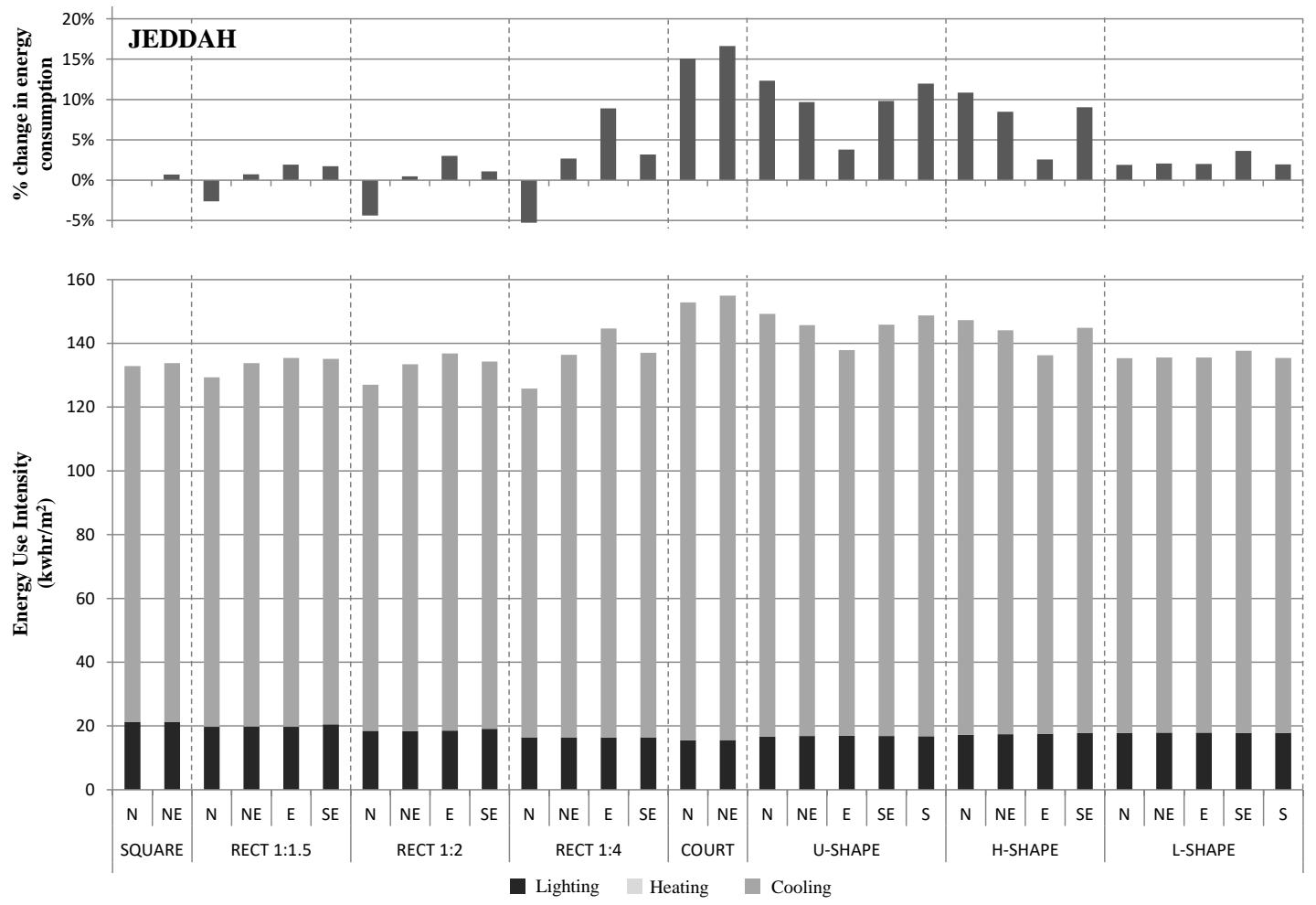
From these results it was evident that forms were more efficient when they faced the north by the longer façade, and thus less subjected to direct solar radiation. Their highest consumption was in the case where longer facades were oriented to east and west. The $\mathrm{H}$ and $\mathrm{U}$-shapes consumed less energy when oriented to the east, as with their east/west longer axis, their longer facade faced the north, Table1.

When oriented to secondary directions, consumption values came intermediate between those of principal orientations for forms of non-symmetric proportions (rectangle cases and $U$ and $H$-shapes), while a small increase occurred in forms of symmetric proportions (square, courtyard building and L-shape), as in the latter ones the secondary orientation lead more surface area to be subjected to direct solar radiation.

Comparison of forms showed that the east oriented $U$ and $\mathrm{H}$-shapes, were of close values to the SE-oriented L-shape, east oriented rectangle 1:2 and to the NE and SEoriented rectangle 1:4, while were much more efficient than the latter when oriented to east.

Cairo and Alexandria showed a similarity in the order of forms according to energy consumption with some differences in values of percentage of change from the base case.

In Cairo, Figure 4, the rectangle cases achieved savings when oriented to north, like in Jeddah. The percentage of savings reached $11.1 \%, 8.7 \%$ and $5.3 \%$ for the rectangles $1: 4$, $1: 2$ and 1:1.5 respectively. These percentages were nearly double those recorded in Jeddah, however, the absolute values of energy consumption in Cairo were still much less their corresponding values in Jeddah. Unlike Jeddah, the $U$ and $\mathrm{H}$-shapes in Cairo achieved savings. This occurred when oriented to east and reached about $3.5 \%$. In orientations other than east, the $\mathrm{U}$ and $\mathrm{H}$ - shapes increased consumption by about $5-8 \%$ and $4-8 \%$ for both forms respectively. The courtyard building was the highest in consumption as it lead to an increase of $8.4 \%$ to $10.8 \%$. However, these percentages were much less than the corresponding ones in Jeddah. The L-shape was very close results to the base case, with minor changes in consumption in all orientations. 
Figure (4) Energy use intensity of forms with walls un-insulated in Cairo and percentage of change in energy consumption compared to the base case.
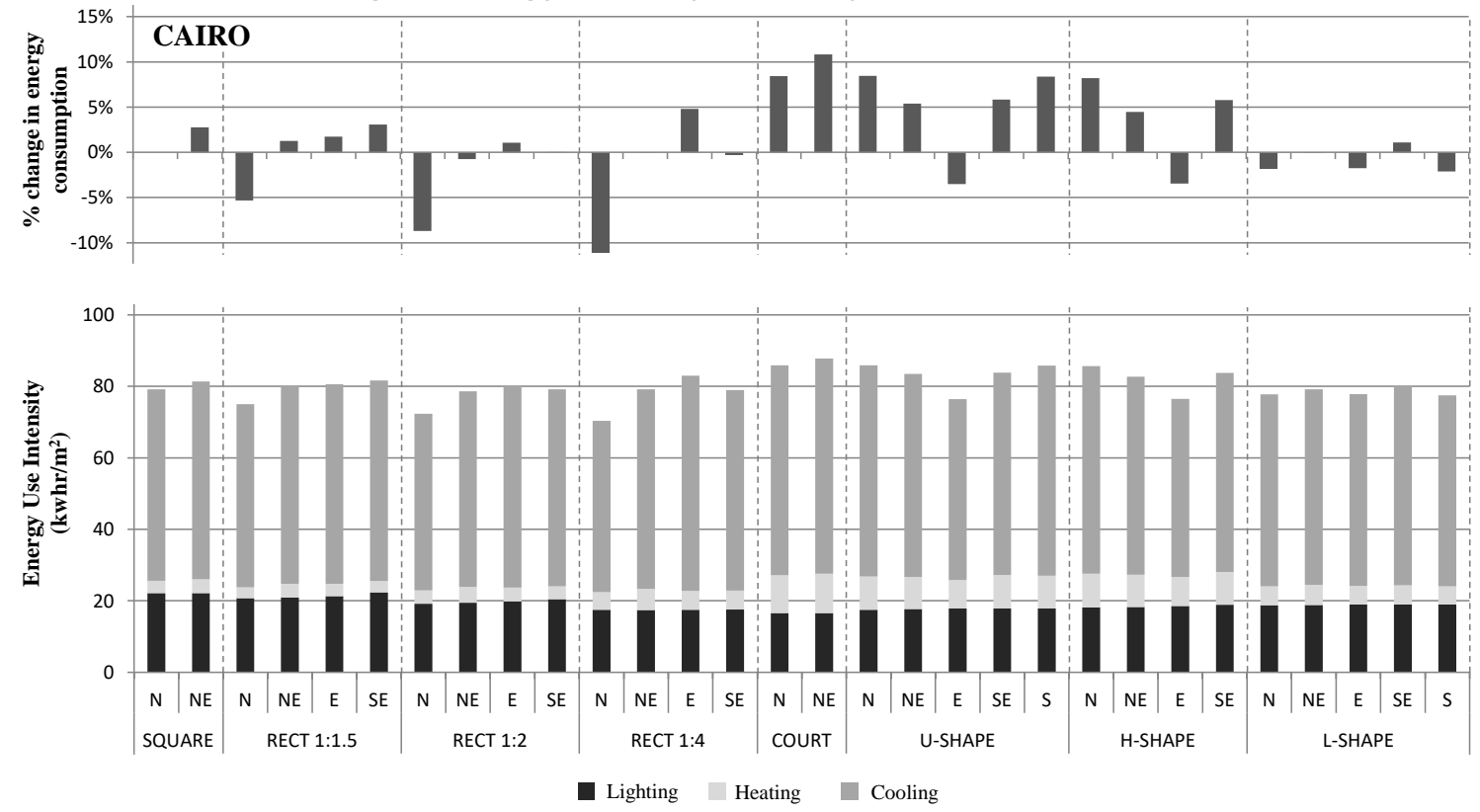

Results in Cairo also showed that the rectangle 1:2 oriented to NE, E and SE, and the rectangle 1:4 oriented to NE and SE were of nearly the same energy performance as the base case with minor savings or insignificant losses. These forms in these orientations in addition to the rectangle 1:1.5 oriented to NE, E and SE were more efficient than $U$ and $\mathrm{H}$-shapes except when the latter ones were east-oriented.

In Alexandria, Figure 5, the hierarchy of forms was the same as that in Cairo, but due to its moderate climate, the forms of large surface area, such as the courtyard building and the $\mathrm{U}$ and $\mathrm{H}$-shapes, did not lead to a large increase in consumption as occurred in Cairo or Jeddah. For example, the NE-oriented courtyard building did not exceed $6 \%$ increase in consumption, while the $\mathrm{U}$ and $\mathrm{H}$-shapes did not exceed $5 \%$ when oriented to north. This can be explained as the moderate outdoor temperature resulted in a smaller temperature difference between indoor and outdoor and thus a less heat transfer by conduction though the building envelope, which in turn made the issue of surface area of a smaller effect in Alexandria than in Jeddah and Cairo. 
Figure (5) Energy use intensity of forms with walls un-insulated in Alexandria and percentage of change in energy consumption compared to the base case.
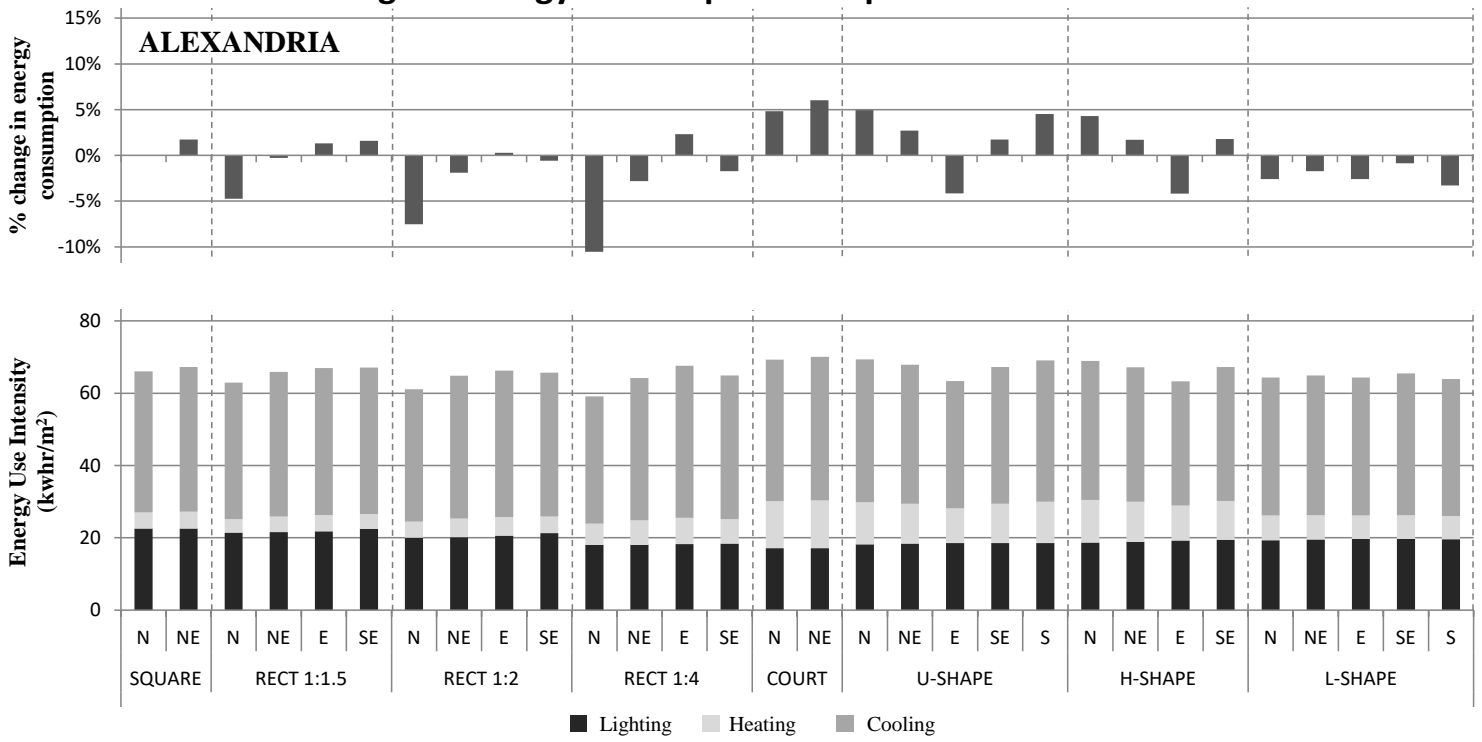

By ranking the most efficient orientation of tested forms, the north-oriented rectangles $1: 4,1: 2$ and $1: 1.5$ showed savings of $10.5 \%, 7.5 \%$ and $4.7 \%$ respectively, followed by east-oriented $\mathrm{U}$ and $\mathrm{H}$-shapes (4.1\%) then the L-shape $(3.2 \%)$, followed by the square then by the north-oriented courtyard building that was $4.8 \%$ higher than the base case. In Berlin, results we significantly different than desert cities. The most efficient form was the square, followed by the rectangles $1: 1.5,1: 2,1: 4$ respectively then the L-shape, then both the $\mathrm{U}$ and $\mathrm{H}$-shapes then by the courtyard building. The difference in consumption between forms reached more than $45 \%$, which was significantly larger than in all other tested cities, Figure 6.

It was clear that the efficiency of building forms was directly proportional to surface area of the building envelope. Unlike desert cities, solar radiation in Berlin was not the major factor, this lead the determining factor to be the difference in temperature between indoor and outdoor which in turn lead the surface area to be the determinant factor. For the same reason, the change in orientation was not significant. 
Figure (6) Energy use intensity of forms with walls un-insulated in Berlin and percent of change in energy consumption compared to the base case.
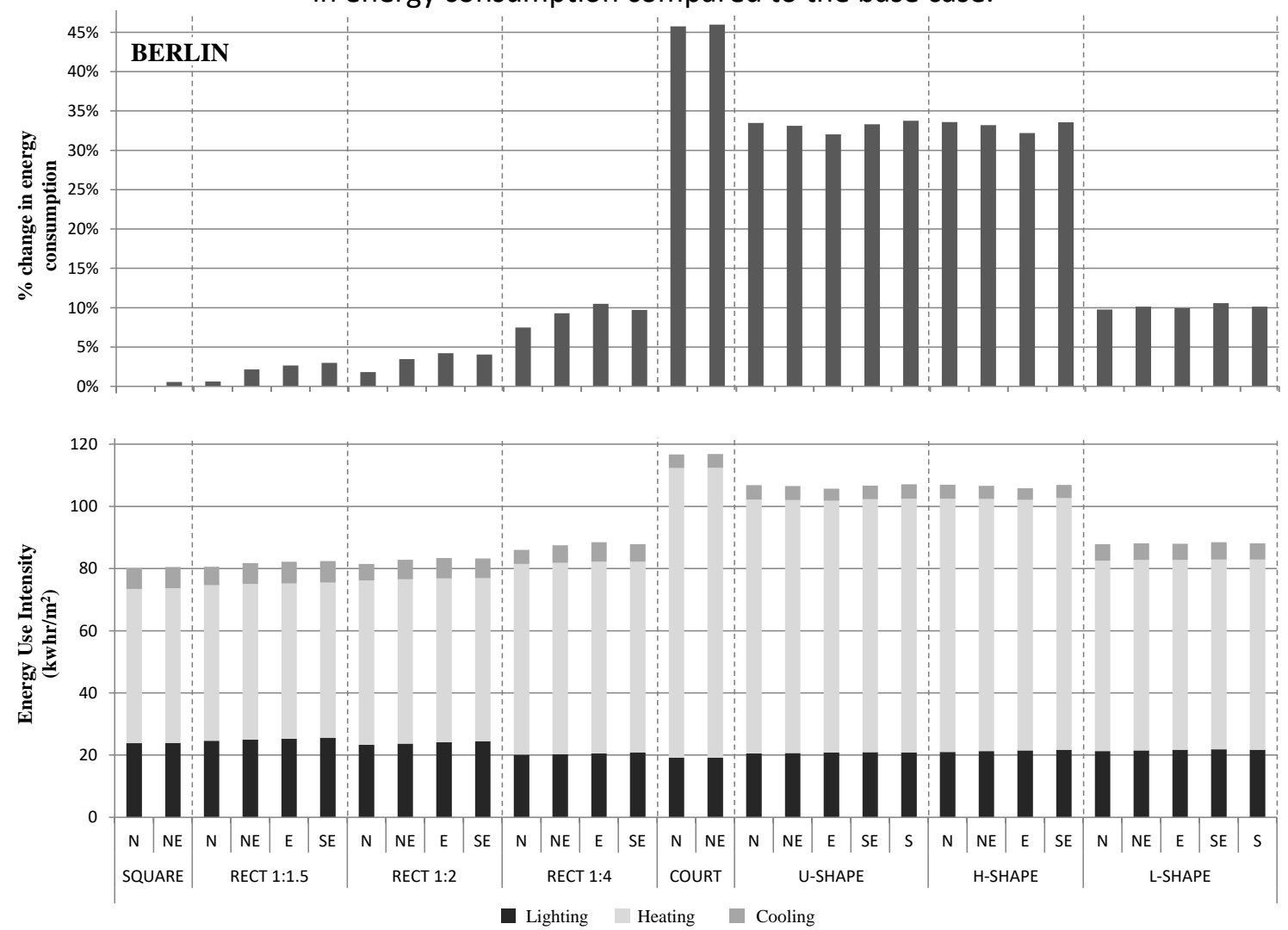

As the square and rectangles 1:1.5 and 1:2 were of small differences in perimeter (64 to $67.8 \mathrm{~m}$ ), their consumption were close with a difference of less that $5 \%$. As the perimeter increased to $80 \mathrm{~m}$ in cases of the rectangle $1: 4$ and the L-shape, their consumption were close to $10 \%$ higher than the square. By reaching $112 \mathrm{~m}$ in cases of $U$ and $\mathrm{H}$-shapes, consumption was more than $30 \%$ higher than the square, while by reaching $128 \mathrm{~m}$ the courtyard building was more than $45 \%$ higher than the square bases case.

\section{Effect of Thermal Insulation}

By adding a layer of insulation to the external walls, a substantial change occurred in results. All forms in all cities achieved savings compared to the base case. Performance of forms of large surface areas improved significantly. In some cases, these insulated forms were more efficient than the best performance un-insulated ones.

In Jeddah, Figure 7, all insulated forms highly exceeded the savings achieved by the most efficient un-insulated form that showed only $5 \%$ savings. The insulated square achieved $15 \%$ savings compared to the base case. The insulated north-oriented rectangle 1:4 along with the east-oriented $\mathrm{H}$ and $\mathrm{U}$-shapes (longer facades facing north) were the best performing cases with savings ranging from $23-25 \%$ approximately. 
The insulated courtyard building achieved $17.7 \%$ savings, indicating more than $32 \%$ improvement over its un-insulated case which was the highest energy consuming form. It also showed more savings than the insulated square and was of nearly the same performance as the north-oriented rectangle 1:1.5 and the L-shape, while resulted in less than $3 \%$ increase in consumption over the north-oriented rectangle 1:2. Also unlike the un-insulated case, the insulated courtyard was either of similar or better performance than all insulated rectangles in all orientations unless rectangles were oriented to north.

The difference in consumption between the best performing rectangle 1:4 and both the east-oriented $\mathrm{H}$ and $\mathrm{U}$-shapes was less than $2 \%$ when insulated, while was $7.5-9 \%$ in the un-insulated case. The difference between the rectangle 1:4 and the courtyard was $6.7 \%$ when insulated while reached about $20 \%$ in the un-insulated case.

Figure (7) Energy use intensity of wall-insulated forms in Jeddah and percent of change in energy consumption compared to the base case.
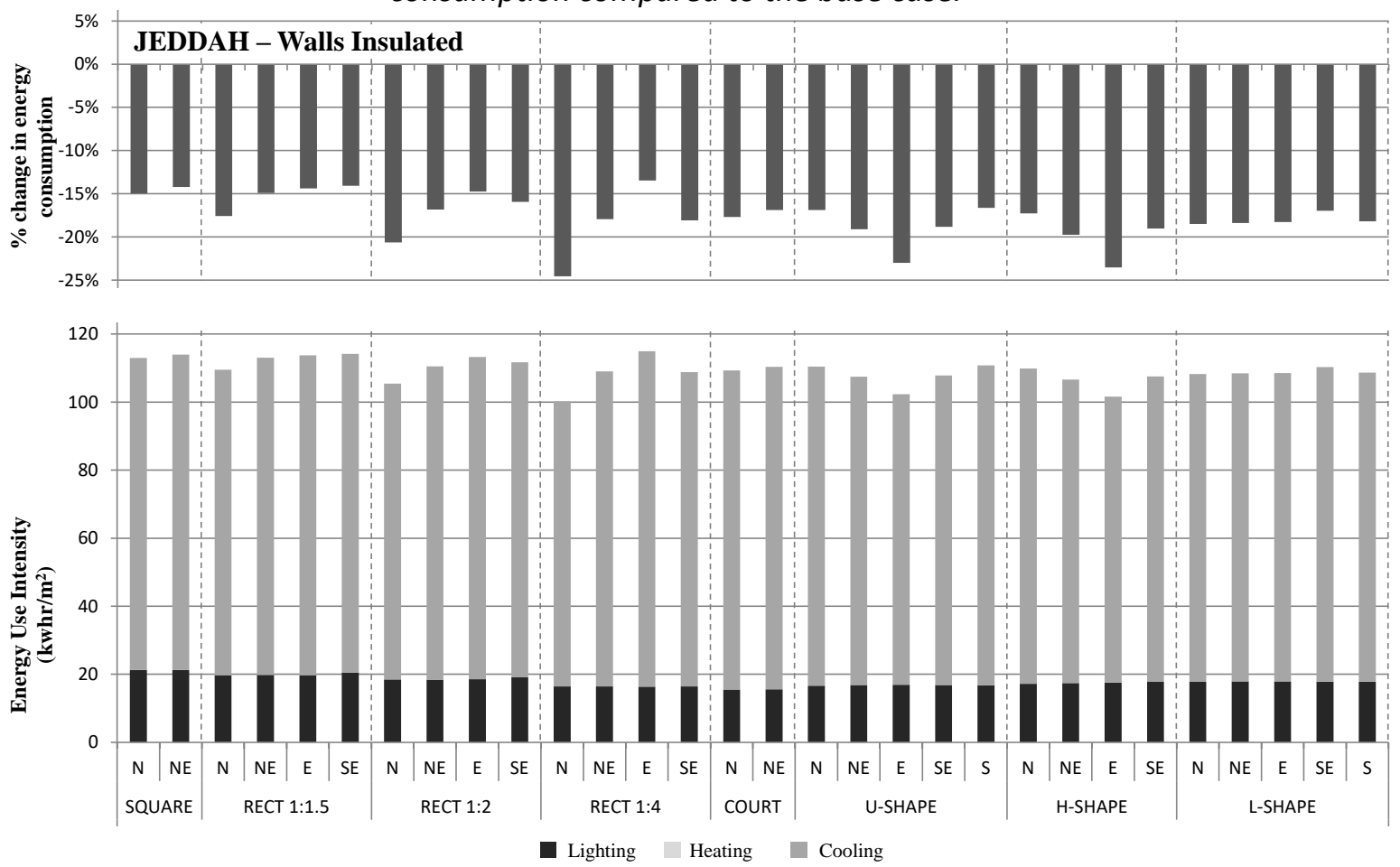

This indicated that adding a layer of thermal insulation in external walls minimized the effect of building form on energy consumption and, moreover, it changed the hierarchy of forms when ordered according to energy consumption.

This can be explained as follows: the building forms differed in both surface area, the availability of daylight and possibility of self-shading. Forms of large surface area (courtyard building and $\mathrm{U}$ and $\mathrm{H}$-shapes) had more potential for self-shading than other forms, which minimized the transmittance of direct solar radiation and thus decreased 
cooling loads. In the meantime, as all zones were daylit, they needed less artificial lighting, and thus decreased the heat emitted which in turn decreased the cooling loads. However these forms had larger surface areas than other forms (up to double that of the base case), which increased heat transfer by conduction across the envelope and significantly increased cooling loads. When insulated, this negative effect is minimized, while the positive effect was still retained. By this, forms of large surface areas had more potential to benefit from large savings due to insulation than ones with smaller surface areas, while keeping the benefits of daylighting and self-shading.

Insulation slightly dampened the effect of orientation. For example the difference between the North-oriented and East-oriented rectangle $1: 4$ was $14.1 \%$ in the uninsulated case, while was $11 \%$ when insulated.

In Cairo, Figure 8, the insulated square recorded one of the lowest savings in insulated forms $(8.3 \%)$, while the east-oriented $\mathrm{U}$ and $\mathrm{H}$-shapes were of the highest savings (24.5\% approx.), to which the north-oriented rectangle 1:4 was of very close savings (23.6\%). The courtyard achieved $18.6 \%$ savings, which was more savings than the Lshape, rectangles $1: 1.5$ and $1: 2$, and then the rectangle 1:4, $U$ and $\mathrm{H}$-shapes except when the latter forms faced the north by it longer facades.

Results in Cairo indicated a total change in the hierarchy of forms when ordered according to energy-efficiency, and that self-shading insulated forms of large surface areas recorded high performance.

Figure (8) Energy use intensity of wall-insulated forms in Cairo and percent of change in energy consumption compared to the base case.
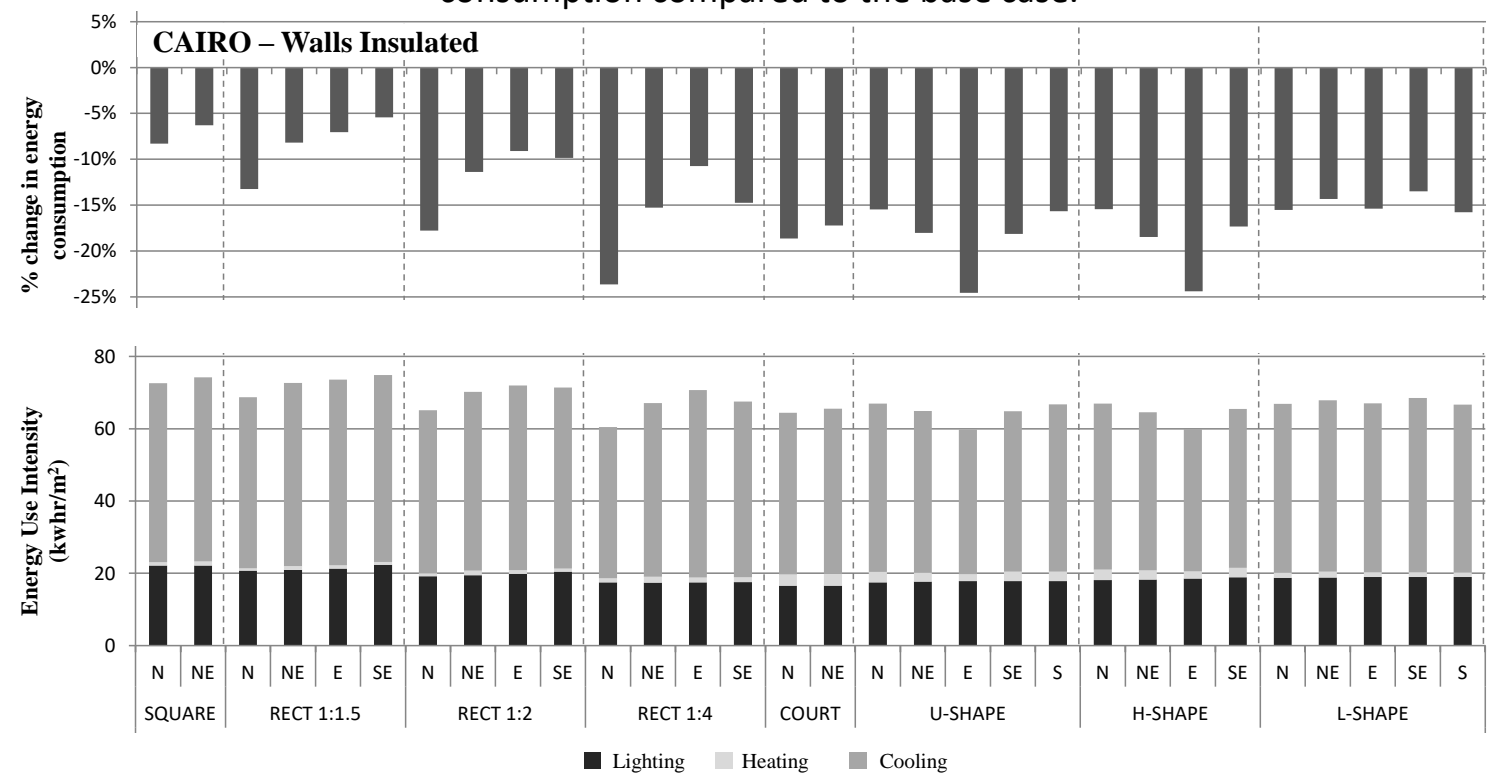

In Alexandria, Figure 9, results showed a similarity to that of Cairo. However, the insulated square recorded only $5.2 \%$ savings, while the east-oriented $\mathrm{H}$ and $\mathrm{U}$-shapes 
were of the highest savings (23\% approx.), showing $2.5 \%$ more savings than the rectangle 1:4. The courtyard building result was very close to the latter form with only $1.5 \%$ difference.

The results of both Cairo and Alexandria indicate that the courtyard building - despite being of the largest surface area - was of close results to the north-oriented rectangles 1:2 or 1:4, and moreover, it was more efficient than the rectangles if they faced other orientations. This showed that insulated courtyard buildings are more liable to be used in Cairo and Alexandria.

Figure (9) Energy use intensity of wall-insulated forms in Alexandria and percent of change in energy consumption compared to the base case.
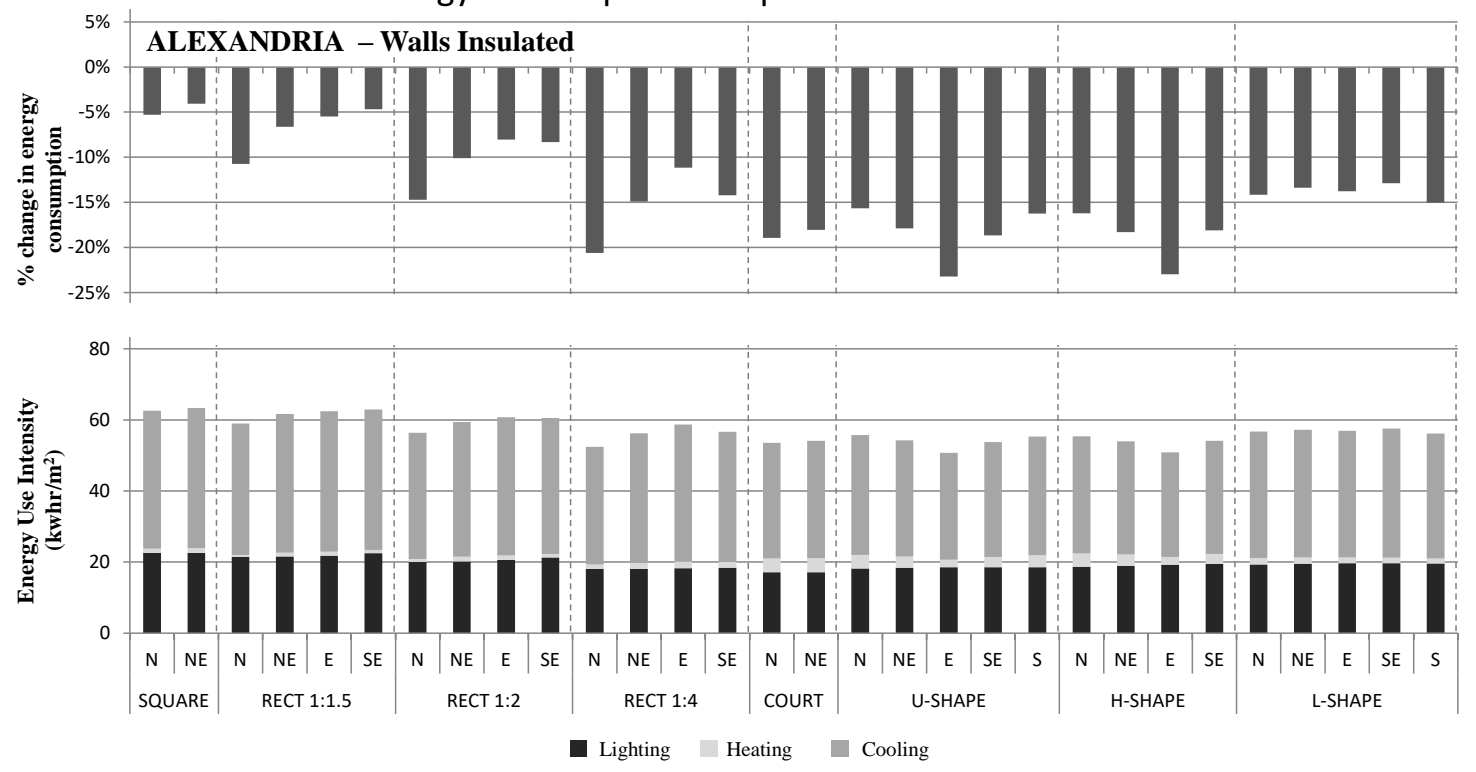

In Berlin, Figure10, all insulated forms achieved large savings compared to the uninsulated base case, which was of the best performance within the un-insulated cases. Unlike desert cities, self-shading forms of large surface area were less in savings than exposed forms of small surface area. The courtyard building was the lowest in efficiency. This showed the high effect of heat transfer by conduction in this city - as it was clear in the un-insulated forms case - and in addition, it showed that self-shading in this city would lead to increase the overall energy consumption by increasing heating loads. The highest savings were achieved by the rectangles, square and L-shape cases that were of close values ranging from $20 \%$ to $25 \%$.

Results of the insulated cases showed that thermal insulation significantly dampened the effect of building form in cities with extreme climates (Jeddah and Berlin), while in cities of mild climates (Cairo and Alexandria) the significance of form was still retained. This can be shown by comparing the range of difference in energy consumption between the form of the highest efficiency and that of lowest efficiency in each city, and of the same orientation (all with their long facades facing north). In Jeddah, this range 
was dampened from $20 \%$ in the un-insulated forms case to only $10 \%$ in the insulated one, while in Berlin, it was dampened from $45 \%$ to only $12.2 \%$. On the other hand, in Cairo and Alexandria, only a minor change occurred in this range from $20 \%$ to $16 \%$ and from $15.3 \%$ to $18 \%$ for the two cities respectively, indicating that in mild cities, the effect of building form is of nearly the same significance, even when insulated.

Figure (10) Energy use intensity of wall-insulated forms in Berlin and percentage of change in energy consumption compared to the base case.
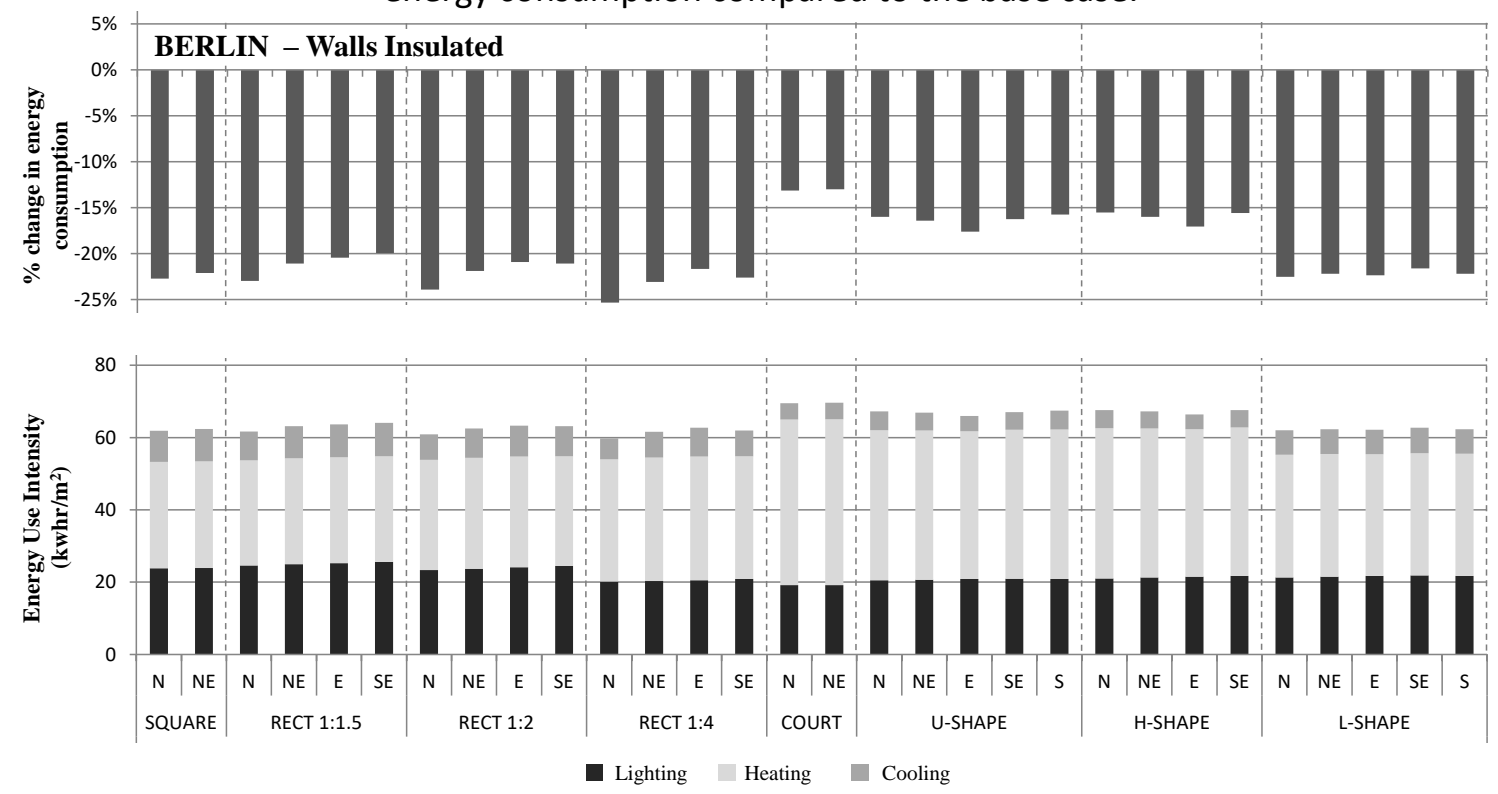

\section{Conclusions}

The effect of building form on energy consumption was determined by calculating the difference between the building forms of highest and lowest energy consumption in each city. It reached nearly $20 \%$ in Jeddah and Cairo, $15 \%$ in Alexandria, while reached $45 \%$ in Berlin. However, the effect of building form should not be separated from that of orientation as the latter was of high significance especially in desert cities.

\section{Form and Orientation:}

The order of building forms according to energy-efficiency varied across cities, while the best orientation of forms did not vary. The highest efficiency was obtained when the longer sides of a form were oriented to north and south, while the highest consumption occurred when they faced east and west. Intermediate orientations resulted in intermediate results. The longer the building form proportions (eg. Rectangle 1:4), the higher the effect of orientation.

In all tested desert cities, the north-oriented rectangle 1:4 was the most efficient form when oriented to north and south, followed by the rectangles $1: 2$ and 1:1.5, while the courtyard building was always the one of highest consumption. This indicated that the 
effect of surface area on energy consumption was higher compared to that of selfshading in the courtyard.

In the extreme hot climate of Jeddah, the $\mathrm{U}$ and $\mathrm{H}$-shape forms - of large surface areas but less than the courtyard building - facing the north with their longer sides ( best orientation) were of higher consumption than the square base case, while in the mild climate of Cairo and Alexandria, they were of lower consumption and thus more efficient. This indicated that the effect of exposed surface area is more significant in the hot climates than in mild climates. Results of courtyard building, $\mathrm{U}$ and $\mathrm{H}$-shapes showed a more liability to be used in mild climates than in extreme hot ones.

In desert cities, the energy was consumed mainly for cooling and lighting, while heating energy was very small. The contrary was in Berlin. The order of forms in Berlin was directly proportional to the surface area of the form, while the effect of orientation was insignificant.

\section{Insulation:}

By adding a layer of $5 \mathrm{~cm}$ thermal insulation, the performance of all forms improved significantly. All forms achieved savings compared to the base case in all cities. Forms of large surface areas were of the highest benefit. The insulated courtyard building in Jeddah achieved $32 \%$ improvement over the un-insulated case. As a larger decrease occurred in forms of larger surface areas, the order of forms according to energy efficiency changed. The smallest improvement occurred in the square building of the smallest surface area.

In Jeddah, the rectangle 1:4, $\mathrm{U}$ and $\mathrm{H}$-shaped forms were of close values and were of highest efficiency followed by the rectangle 1:2. The courtyard building, L-shape and rectangle 1:1.5 were of close values that were of better performance than the square. The difference between the rectangle 1:4 and the courtyard building decreased to $6.7 \%$ when insulated, instead of $20 \%$ in the un-insulated case. In Cairo and Alexandria, the $U$ and $\mathrm{H}$-shapes exceeded the savings of the rectangle 1:4 and were of highest efficiency, and the three of them were directly followed by the courtyard building. In Berlin, the differences between forms were dampened by insulation. The forms of large surface area were of higher consumption than those smaller ones that were nearly of close energy consumption values.

In general, the effect of adding a layer of thermal insulation to external walls on energy consumption was higher than that of building form and orientation in all cities.

\section{Limitations}

The tested forms were limited to the $256 \mathrm{~m}^{2}$ floor area, as described above. This resulted in rather 'thin' forms in some of the tested cases such as in $\mathrm{U}, \mathrm{H}$ and courtyard forms. In 
these cases, several zones were exposed to the outdoor environment from two or three sides. If the building area was larger, fewer zones would be exposed from multiple sides, possibly resulting in a different performance. This aspect could be addressed in a future study.

\section{Acknowledgements}

This research is financially supported by King Abdullah University of Science and Technology (KAUST) as part of the Integrated Desert Building Technologies Project IDBT (Award no.UK-C0015).

\section{References}

1. Depecker, P. et al., (2001). Design of buildings shape and energetic consumption. Building and Environment, 36(5): p.627-635

2. Oral, G. K. and Yilmaz, Z., (2003). Building form for cold climatic zones related to building envelope from heating energy conservation point of view. Energy and Buildings 35: p 383388.

3. Okeil, A. (2010). A holistic approach to energy efficient building forms. Energy and Buildings 42 : p 1437-1444

4. Hachem, C., Athienitis, A. \& Fazio, P., (2011). Parametric investigation of geometric form effects on solar potential of housing units. Solar Energy, 85(9): p.1864-1877.

5. Hachem, C., Athienitis, A. \& Fazio, P., (2011). Investigation of solar potential of housing units in different neighbourhood designs. Energy and Buildings, 43(9): p.2262-2273.

6. Kämpf, J.H. \& Robinson, D., (2010). Optimisation of building form for solar energy utilisation using constrained evolutionary algorithms. Energy and Buildings, 42(6): 807-814.

7. Kämpf J., Montavon M., Bunyesc J., Bollinger R. and Robinson D., (2010) Optimization of building's solar radiation availability. Solar energy 84: p. 596-603

8. Ratti, C., Raydan, D. \& Steemers, K., (2003). Building form and environmental performance: archetypes, analysis and an arid climate. Energy and Buildings, 35(1): p.49-59.

9. Muhaisen A.S., Gadi M.B., (2006). Shading performance of polygonal courtyard forms, Building and Environment 41: p. 1050-1059.

10. Muhaisen, A.S., 2006. Shading simulation of the courtyard form in different climatic regions. Building and Environment, 41(12), p.1731-1741.

11. Al-Hemiddi N. \& Al-Saud K. (2001). The effect of a ventilated interior courtyard on the thermal performance of a house in a hot-arid region, renewable energy, 24, p 581-595

12. Sadafi, N. et al., 2011. Evaluating thermal effects of internal courtyard in a tropical terrace house by computational simulation. Energy and Buildings, 43(4), p.887-893

13. Rajapaksha, I., Nagai, H. \& Okumiya, M., 2003. A ventilated courtyard as a passive cooling strategy in the warm humid tropics. Renewable Energy, 28(11), p.1755-1778. 
14. Safarzadeh, H. \& Bahadori, M., (2005). Passive cooling effects of courtyards, Building and Environment, 40(1): p.89-104

15. Al-Tamimi N., Fadzil S. and Harun W., (2011). The effects of orientation, ventilation, and varied WWR on the thermal performance of residential rooms in the tropics. Journal of Sustainable Development, 4 (2): p. 142-149.

16. Morrissey, J., Moore, T. \& Horne, R.E., (2011). Affordable passive solar design in a temperate climate: An experiment in residential building orientation. Renewable Energy, 36(2): p.568577. 